\title{
On the Occasion of the 150th Birthday of Wilhelm Ostwald Three Essays on his Discoveries and Proposals
}

\author{
Hermann Berg
}

\section{Third Essay: How to find out creative students?}

Ostwald was asked by the Japanese Ministry for Education about 1900 [1]; what are the criteria for creative pupils and students and how to find them out early? In order to give a reasonable answer, he studied the development and life of outstanding researchers of the $19^{\text {th }}$ century. In his book" Grosse Männer ( Great Men), Studien zur Biologie des Genies" [2] he analysed psychoanlytically Humphry Davy (chemist), Julius Robert Mayer ( physician), Michael Faraday (chemist), Justus Liebig (chemist), Charles Gerhardt (chemist), Hermann Helmholtz (physiologist, physicist).

At first Ostwald described their early "curriculum vitae".

$H$. Davy made experiments, but did not learn Latin language and he was a bad school-boy.

J. R. Mayer was excellent in mathematics, but not in classical languages.

M. Faraday was an autodidact and was happy to become an assistant of $\mathrm{H}$. Davy.

J. Liebig experimented in the laboratory of his father, however, left the gymnasium in the premature age of 15 years.

Ch. Gerhard was a clever school-boy and went in the age of 15 years to the polytechnicum Karlsruhe.

$H$. Helmholtz was a sickly child, had an excellent teacher in mathematics and started in the age of 17 years at the medical Friedrich-Wilhelm Institut.

Ostwald's conclusion was:

nearly all great men - he studied- were bad school-boys and don't like mental authority and learning of old languages instead of natural sciences.

Their social background was mostly middle-class or lower-class, but not from the aristocratic upper class.

The criteria for early recognition of creative talents Ostwald presented on the celebration for the 
erection of a monument for Ernst Abbe ( physicist of the C. Zeiss Factory) at Jena 1911 [3]:
A) precociousness,
B) school-boy (-girl) aims at higher knowledge - especially in one direction -as his(her) curriculum shows,
C) therefore increasing conflicts arise in the school. The description of the teacher fits not always, namely they change to disobedience,
D) They are working with high intensity in one direction only,
E) They show inventor and designer abilities and are interested in collections, essays, physical and chemical experiments,

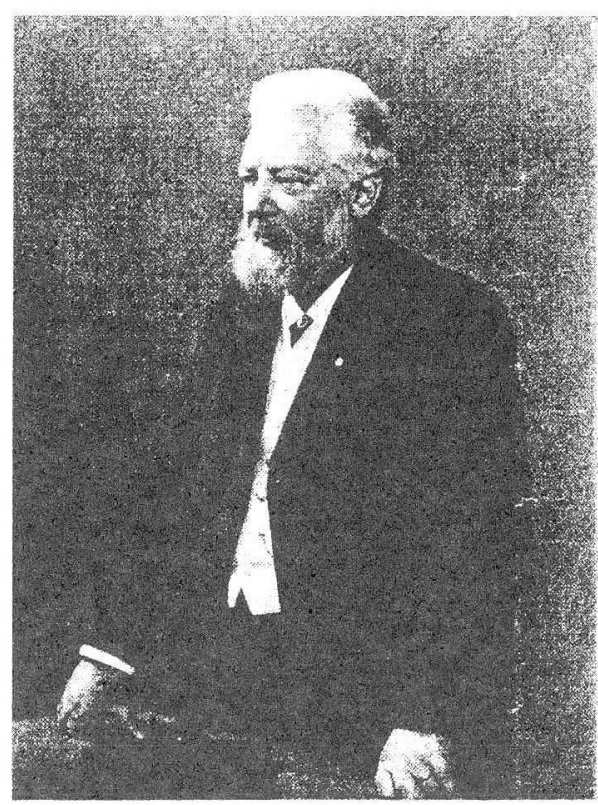

F) often they are initiators for common activities together with other fellows.

G) They find all kinds of opportunities to receive books of their mental training.

H) They have elder friends in their family supporting them in their efforts. Such a friend can give the true information on them.

I) The possibility to work freely in the chosen field of research would seem them as the maximum of satisfaction.

J) Their schoolmates face them with a mixture of mockery and respect. Which of these is dominant depends on their dispositions and also on the position of their parents.

One should take into account that a "brave" pupil or student with the best notes will not become of necessity a creative scientist or engineer, who is able to fulfil high achievements [4]. The approach to research needs reproductive intelligence consisting of observation and abstraction ability, memory, reflection, logic, as well as creativity characterized by meaningful imagination, which combines scientific knowledge with new ideas( the basis of originality) leading to inspirations, which are supported by the subconscious, working mainly during relaxation. For development novel idea it needs unconventional thinking, precision, self-criticism, and willpower. Ostwald distinguishes in respect to working style: the fast-thinking, broad minded 
"Romantiker" from the careful, profound "Klassiker". Both should be supported by a scientific organizer, who arranges team work and transform basic results into practical applications. Furthermore there are differences between the discoverer, whose achievement is reproducible, generally valid, and surprising on the one hand and the inventor $[5,6]$ who must take into account the necessity of his time. As "Klassiker" are described by Ostwald: J. R. Mayer, M. Faraday. F. Wöhler and H. Helmholtz having a more phlegmatic until melancholic temperament, whereas $\mathbf{H}$. Davy, J. Liebig, and Ch. Gerhardt as "Romantiker" show a sanguinic until choleric character. In the late $20^{\text {th }}$ century one can count to "Klassiker": Max Planck, Max von Laue, Ludwig Boltzmann, Walther Nernst, Adolf Butenandt, Jaroslav Heyrovsky, Max Volmer, Otto Warburg and to "Romantiker": Wilhelm Ostwald, Svante Arrhenius, Frilz Haber, Alexander Frumkin, Karl Bonhoeffer, Albert Einstein, Manfred von Ardenne.

On the top of his "pyramid of science" [4] Ostwald put the research of the character of ingenious scientists, named genealogy (analysis of ingenuity) followed below

by sociology

psychology

medicine

biology

chemistry

physics

geometry

mathematics

logic.

Every level of science needs the knowledge of its foregoing below.

Ostwald pioneering evaluation of natural scientists has been extended by S. Ramon y Cajal [9], who also pointed out, a) which properties of character should be a prerequisite, b) which type of researcher is able to break through, c) which support from the society must be necessary.

Hans Selye [10] gave further answers on research questions in his book: "From Dream to Discovery, on being a scientist":

- why research? 
- who should research?

- what should be researched?

- how should research be guided?

- how must be worked?

- how should be thought about?

According to him originality included: independence of unprejudiced thinking, imagination, intuition, ingenuity.

Stimulating efficacy the student may have a shining example, e. g. of a famous scientist, At Ostwald's heritage, the "House Energy" at Großbothen near Leipzig, there were meetings founded in 1977, where a famous scientist presents general lectures on his development mostly for students. For instance the inventor Manfred von Ardenne [9] admonished young fellows:

"Not to be dreamy during your life, but realized your dreams".

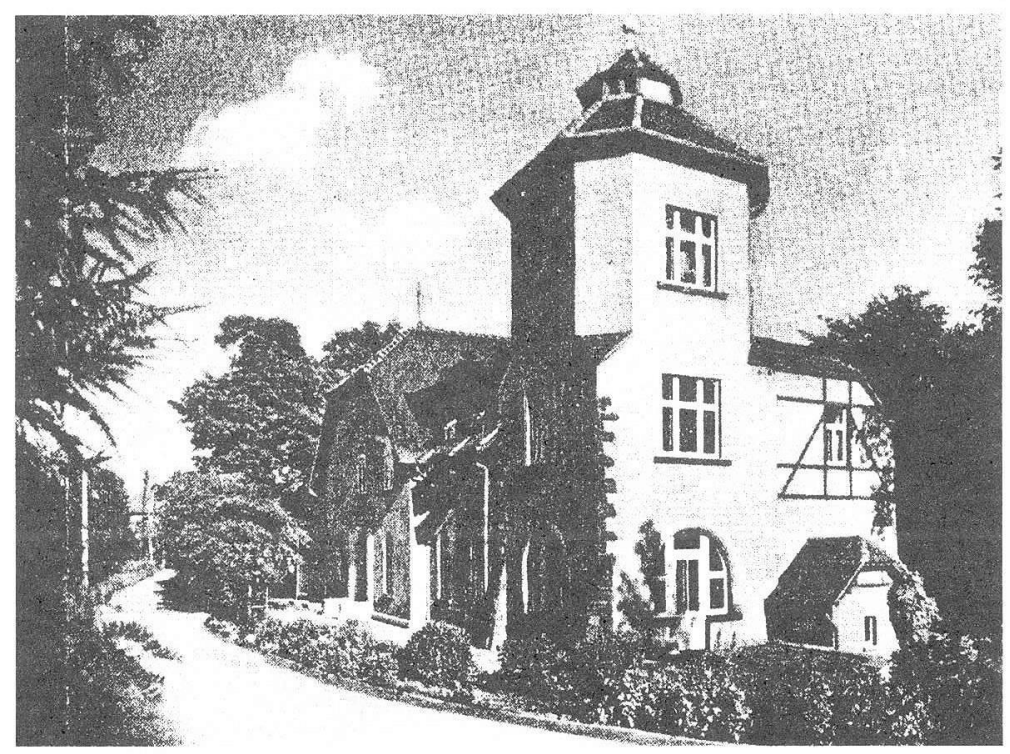

"Haus Energie" 


\section{References}

1/ Ostwald, Wilhelm: Lebenslinien: eine Selbstbiographie. 3 Bde, Klasing, Berlin: 1926/27-reprint in one vol.2003

2/ Ostwald, Wilhelm: Große Männer: Studien zur Biologie des Genies. Bd. 1.: Akad. Verlagsges., Leipzig, 1909.-6. Auflage 1927

3/ Ostwald, Wilhelm: Abbe unser Führer: Vortrag, gehalten zur Einweihung des Abbe-Denkmals am 31. 7. 1911 in Jena. In: Ann. d. Naturphil. 11 (1912), S. 1-16

4/ Ostwald, Wilhelm: Schöpferische Jugend. In: Berliner Illustr. Ztg. [1931-12-25] = Nr. 52, S. 2051-2052. Auch in: Gedanken zur Biospäre. Sechs Essays (hrsg. von H. Berg) Akad. Verlagsges., Leipzig, 1978 S. 74-80.- (Ostwalds Klassiker 257)

5/ Ostwald, Wilhelm: Erfinder und Entdecker. Rütten \& Loening, Frankfurt/M., 1908, S. 22-23.-(Die Gesellschaft 24)

6/ Ostwald, Wilhelm: Die Technik des Erfindens (1907): Vortag in der Monatsvers. der "Oesterr. Ges. zur Förderung der chem. Industrie" in Prag am 23.02.1907. In: Die Forderung des Tages. Leipzig: Akad. Verlagsges., 1910, S. 155-161. Auch in: Forschen und Nutzen: Wilhelm Ostwald zur wissenschaftlichen Arbeit...Herausgeber: G. Lotz; L. Dunsch; U. Kring. Akademie- Verl., Berlin, 1978, S. 23-27.-(Beiträge zur Forschungstechnologie So.-Bd.1)

7/ Ramon, Y Cajal, S.: Regeln und Ratschläge zur wissenschaftlichen Forschung. Reinhardt, München, 1933.

8/ Selye, Hans: From dream to discovery: on being a scientist. Mac Graw-Hill, New York, 1964.

9/ Von Ardenne, Manfred: Eine glückliche Jugend im Zeichen der Technik. Urania, Leipzig, 1965. 